\title{
Anafre River Management Based on Local Communities in Reducing the Impact of Sedimentation in Gulf of YOS Sudarso
}

\author{
Annita Sari ${ }^{*}$, Dahlan ${ }^{1}$, Mahatma Lanuru $^{2}$ \\ ${ }^{1}$ Yapis Papua University, Jayapura, Indonesia \\ ${ }^{2}$ Hasanuddin University, Makassar, Indonesia \\ *annitasarie@gmail.com
}

\begin{abstract}
The life of coastal communities is always associated with water. Anafre River estuary is one of the river estuaries that empties directly into the Gulf of Yos Sudarso. The amount of particles swept away and buried in estuary sedimentation Anafre inflicts not only the river but the Gulf of Yos Sudarso. Declining water quality of the Gulf of Yos Sudarso is caused by the influx of water from the Anafre River, whereas all Anafre River watersheds are located in close proximity to residential areas. This study aims to determine the level of public knowledge on the effects of sedimentation and community based management. Data are collected by field observations and interviews with the community, and analyzed using the qualitative descriptive method. The results showed that the community plays an active role in the maintenance and utilization of the Yos Sudarso area, because the gulf of Yos Sudarso serves as transportation routes, tourist areas, and workplaces (fishermen). The maintenance of water environment in river estuaries and the gulf is based on the principles of awareness and cooperation without ignoring the people's culture.
\end{abstract}

Keywords: The Gulf of Yos Sudarso, Anafre estuary, community-based management

\section{Introduction}

Anafre river is one of the rivers in the city of Jayapura which empties into the Gulf of Yos Sudarso. The formation of sedimentation in the Anafre river channel Anafre has caused changes in river conditions and characteristics (sandy soil), with significant the elevation difference between the upstream and downstream. The elevation difference causes sediment to drift upstream to downstream/estuary and settles. Sedimentation in the estuary is estimated to come from materials from Anafre brought to land due to deforestation in the protected forest and land use in the hillside, transported streams or runoff water and deposited on the mouth of the Anafre river. In addition, sedimentation is also due to the influx of sewage from the business district activities Ampera and household waste from residential areas. Sedimentation impacts not only the Anafre estuary but also the Gulf of Yos Sudarso. The Gulf of Yos Sudarso is an area of passenger port and capital goods as sea transportation for people moving in and out of Papua to other regions, as well as transport ships carrying containers to various destinations along the Yos Sudarso bay, Because the gulf lies in the downstream, the flow at the mouth is greater than the upstream; as a result, streams carry large sediments and materials increase in volume. The large volume of sediment transport depends on changes in the rainy and dry seasons and is also influenced by human activity. The high activity in the waters of the gulf of Yos Sudarso area indirectly causes a decline in water quality. The Gulf of Yos Sudarso is a coastal region that is open access, common property, and subject to activities of coastal communities and complex dynamics. Sustainable development in the region requires an integrated and sustainable approach that includes community participation. Furthermore, the approach does not take into account the interaction between ecological principles and culture. This is feared to cause imbalance in the management areas that are not environmentally friendly. This study aims to determine the level of public knowledge on the effects of sedimentation and community-based water management.

\section{Literature Review}

Estuary is the most downstream part of the river that directly meets the sea. As a part of the river, it is affected by tides. River water with varying chemical and physical characteristics mix with lake water in 
coastal wetlands that are affected by tides and storms just like estuaries along the oceanic coasts. These freshwater estuaries also provide many of the ecosystem services and functions that brackish estuaries do, such as serving as natural filters for runoff and providing nursery grounds for many species of birds, fish, and other animals. Society is a unit consisting of people who live in certain areas and work together in groups, based on the same culture to achieve the same interests. While a society has generally the same territory with geographical boundaries that have been set, these limits are an indication of the existence of a community group. A human society is a group of people involved in persistent social interaction, or a large social grouping sharing the same geographical or social territory, typically subject to the same political authority and dominant cultural expectations. Human societies are characterized by patterns of relationships (social relations) between individuals who share a distinctive culture and institutions; a given society may be described as the sum total of such relationships among its constituent members. In the social sciences, a larger society often evinces stratification or dominance patterns in subgroups. Community-based management can be defined as a system of natural resource management in a place where the local people in the area are actively involved in the management of natural resources contained therein (Kay and Alder, 1999). Community-based management can be categorized into two groups : traditional and neotradisonal (Dahuri, 2003). Traditional community-based management is generally based on customs and traditions that have been in the community for a long time, for example SASI in Maluku (Nikijuluw, 2002). While neotraditional community-based management is performed under rules established by the community itself or facilitated by the government or relevant stakeholders.

\section{Methodology}

Data collection is done by combining various methods of research; i.e., interviews, focus group discussions (FGD), observation, and literary search for secondary data. Target respondents interviewed are fisherman and people who live along the Anafre river, as well as the Kayopulau fishermen communities in the Gulf of Yos Sudarso.

Data Analysis: The collected data will be analyzed using the descriptive qualitative method. Descriptive Qualitative research is a procedure that uses descriptive data in the form of words written or spoken by the people and actors that can be observed. Qualitative approach, is a research procedure that produces descriptive data in the form of speech or writing and behaviors that can be observed from the subject itself (Moleong, 2000).

Sampling Location: samples were collected at the Gulf of Yos Sudarso region, and the estuary of Anafre River, both are located in Jayapura City.

\section{Figure 1 : Sampling Location}

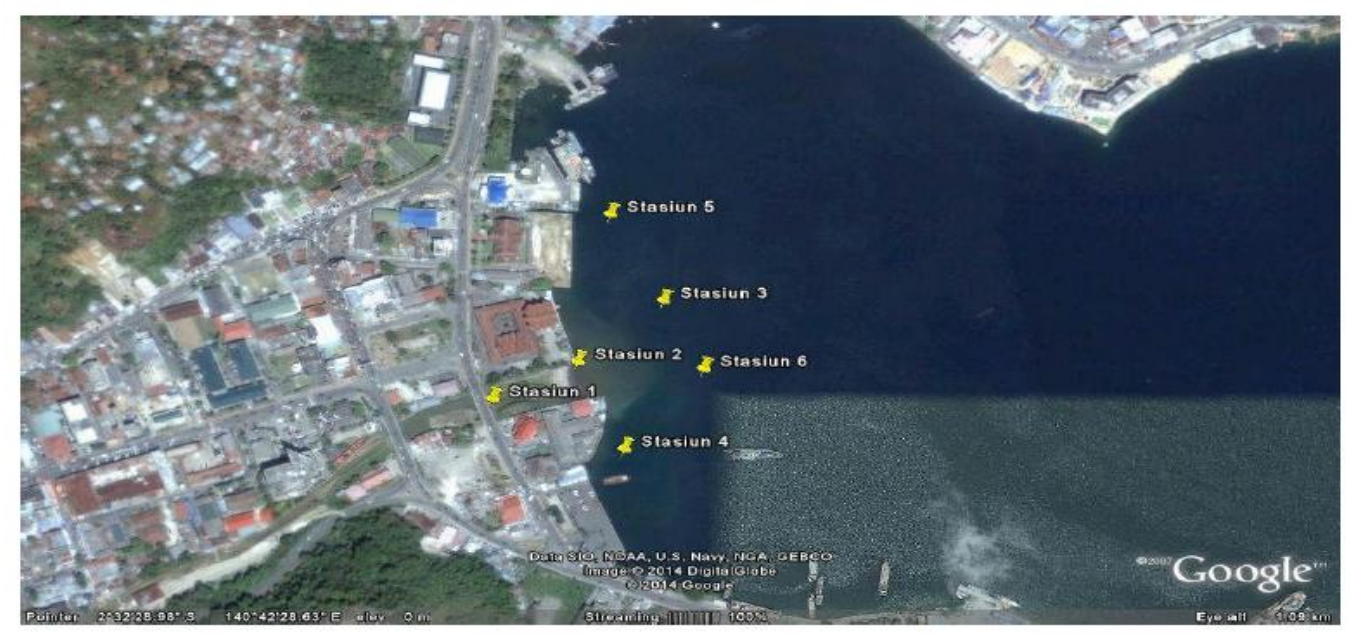

\section{Result}


Geographical conditions, Hydrology and Climate: Jayapura city is the capital of Papua province, with an area of about $940 \mathrm{~km}^{2}$, or about $0.22 \%$ of the total area of the Province of Papua. The city is geographically located at $1028^{\prime} 17.26 "-3058^{\prime} 0.28$ " south latitude and $137034^{\prime} 10.6 "-1410$ 0'8.22' east longitude. It is also located at the edge of the Gulf of Yos Sudarso with the following borders (Source: BPS Jayapura City, 2010):

a. Pacific Ocean in the north

b. $\quad$ Arso district in south

c. State of Papua New Guinea (PNG) to the east

d. Depapre Sentani District and Jayapura regency in the west

The climate of Jayapura City is tropical wet. The average air temperature ranges from $30^{\circ} \mathrm{C}$ minimum temperature to $29^{\circ} \mathrm{C}$, and a maximum air temperature of $31.8^{\circ} \mathrm{C}$. Rainfall varies between $45-255 \mathrm{~mm} /$ year with the rainy days on average between 148-175 days of rain/yr. Humidity varies between $79 \%-81 \%$. According to the records of the 2005 Jayapura Region V Meteorology and Geophysics bureau, the city's average air temperature is between $23.0^{\circ} \mathrm{C}-32.2^{\circ} \mathrm{C}$. Air humidity ranges between $77 \%-82 \%$, with the highest rainfall in March 2005 recorded at $500 \mathrm{~mm}$ and the lowest in December 2005 at $100 \mathrm{~mm}$. Hydrology conditions in Jayapura is generally parallel to the direction of flow of its major rivers, namely Acai River, Entrop River, Anafre River, Kloofkamp River, APO River, Tami Dok IX River, all of which flow into the Pacific Ocean, except for one river namely Kampwolker Buper river that empties to Sentani Lake. The rivers located in the city of Jayapura that generally flows to the north and south are separated by a morphological topography which stretches from west to east, so as to separate the flow of surface (Surface run-off) at two macro rain catchment areas. Jayapura city has 17 rivers, namely: North Jayapura District: Anafre river, Kloofkamp, APO, Yapis dan Dok IX; North Jayapura District: Acai river, Siborogonyi, Entrop I, II, III dan Hanyaan; Abepura District: Kampwalker river, Buper river; and Muara Tami District : Tami river, Skamto river, and Buaya river.

The condition of the Anafre River and the Gulf of Yos Sudarso: In my previous study, I found that the brownish color and smell of the water are due to a mixture of mud and organic and inorganic wastes from streams that empty into the sea. Brightness value is below the limit of water quality standards: water under 1 meter depths is murky due to a brownish color due to the suspended sludge/soil washed from the river flow, while water at station 3 (Lantamal X) and station 4 (Rear Terminal) is still in good condition. The value of the average temperature at each research location is almost the same range, namely $29^{\circ}-30^{\circ} \mathrm{C}$. The temperature at each station is in a good/normal state. The DO value of the results of the research study at any location in a good/normal state with values $>5$ for marine life as well as for marine tourism. The COD value is still in the category of good/normal. The value of metal content of copper $(\mathrm{Cu})$ in stations 3 (Lantamal X), 4 (Rear Terminal), and 5 (Estuary) fall into the category of normal with average values ranging from $0,48-0,79$, and for Station 1 (Bridge) and 2 (DPRD) levels of copper in the water can still be tolerated, with the value of the content at 1.22 to 2.47 in the category of slightly polluted. The Salinity values at each station are in the good/normal state for freshwater, brackish, and sea water. Sedimentation conditions in the Gulf of Yos Sudarso models show the conditions in which sediments out of the Anafre river are composed of coarse sand, the spread of suspended sediments coming out of the river Anafre is confined to the mouth of the river. The distribution of suspended sediment will move further towards the sea through the Gulf of Yos Sudarso and reaches seagrass beds and coral reefs on the Kayupulau if sediment materials out of the Anafre river are composed of mud (silt and clay) (Sari \& Dahlan, 2015).

\section{Figure 2: Models of Sedimentations out of the Anafre river to Gulf Yos Sudarso}




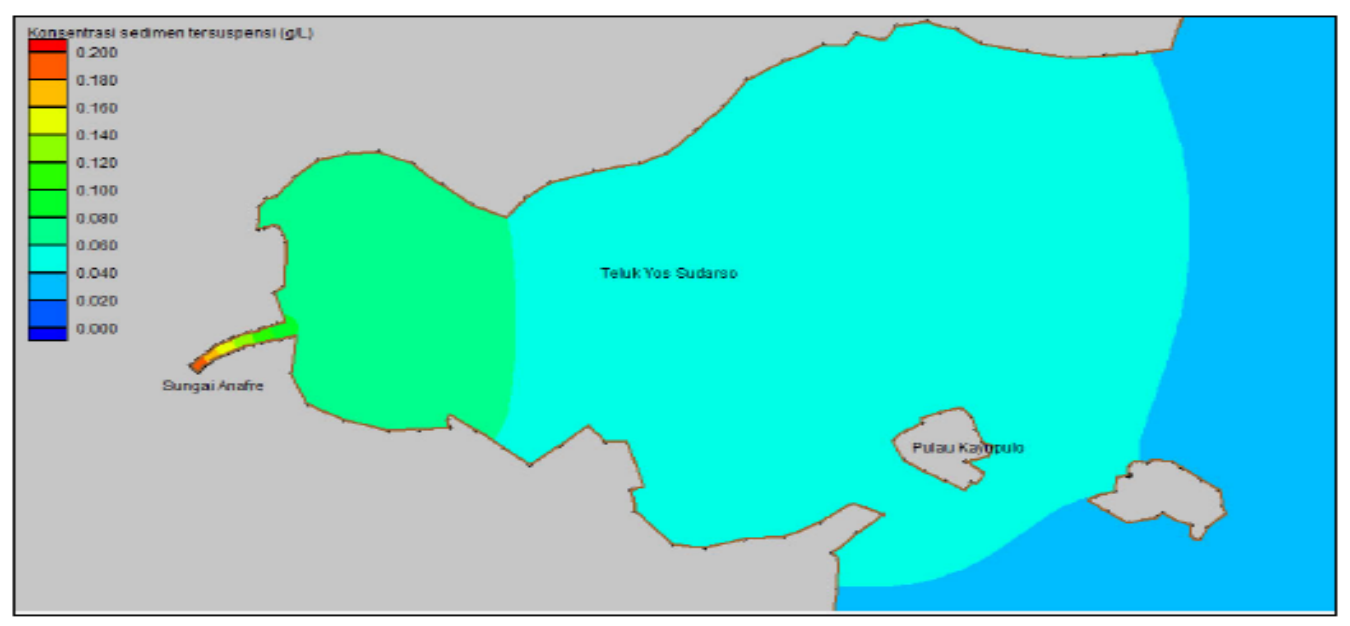

Utilization Society: Results obtained by analysis on Kayu pulau Communities shows that the majority of local communities there work as a civil servant in Jayapura and fishing is a side job, with other side jobs which include driving taxi boats. The use of clean water is provided by PDAM, facilities and infrastructure are also readily available and complete, public services such as early childhood education and city cleaning services are available, and people generally use oil stoves for cooking. Low quality housing is evident in Kayupulau, as there are still houses which discharge wastes directly into the water. People are aware that water is really important for them. The interviews results showed that Anafre River and the Gulf Yos Sudarso is very important to the people (75\%); while $25 \%$ respondents stated that these waters is important (Figure 3). The estuary of Anafre River and the Gulf of Yos Sudarso become very important due to their locations because they are used for transportation, recreation, inspiration, medicinal sources, fishing, and to sustain modern living necessities. Estuaries also act as nurseries for baby fish, better known as juveniles. On the Gulf there are Coral reefs and seagrass that act as shelters where fish can find food and protect themselves from predators. Coral reefs and seagrass provide protection against shoreline erosion and inundation from the ocean.

\section{Figure 3: The Importance of the Anafre River and the Gulf of Yos Sudarso}

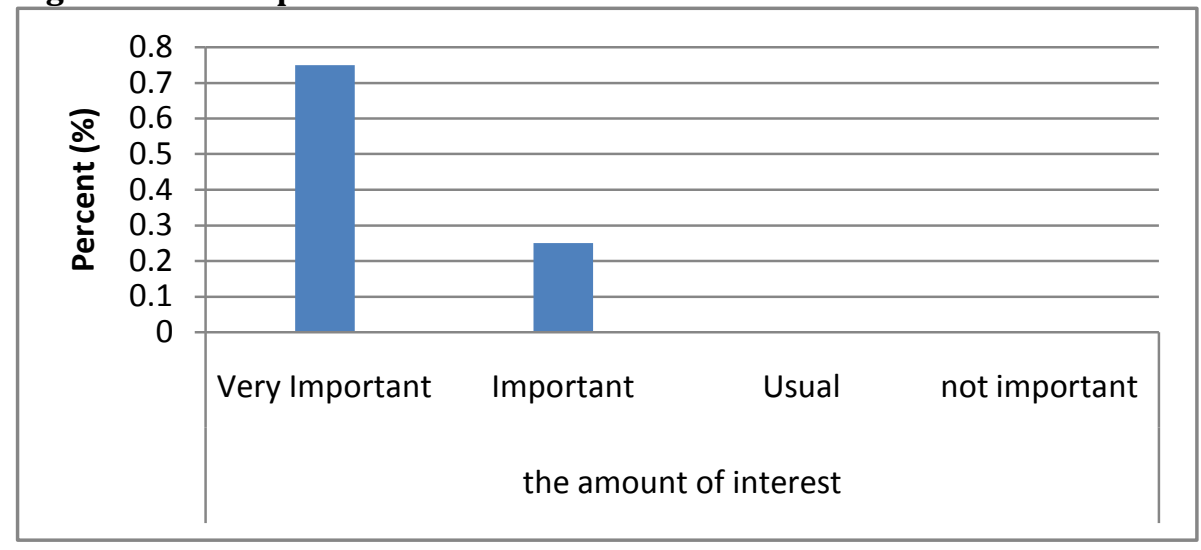

Figure 4 shows respondents' persceptions or local wisdom on the importance of keeping the river and sea clean (45\%). Local Wisdom refers to the cumulative and complex bodies of knowledge, know-how, practices and representations that are maintained and developed by peoples with extended histories of interactions with the natural environment, or how young people inherit knowledge from their parents about how to protect waters and why waters is really important for them. For example, the Kayupulau community keeps the Gulf of Yos Sudarso clean because they believe that it is gifted by God so they must protect the water. Besides that, if the sea is clean, the coral is healthy and can increase fish population. Concerning sources of information, most respondents (20\%) obtain information from the Media and formal/informal sources. This means most of their knowledge come from the internet, radio dan television. Other sources from which 
respondents get information about keeping their environment is formal education and from the environment $(10 \%)$.

Figure 4 : Knowledge Sources about the benefits of aquatic environment

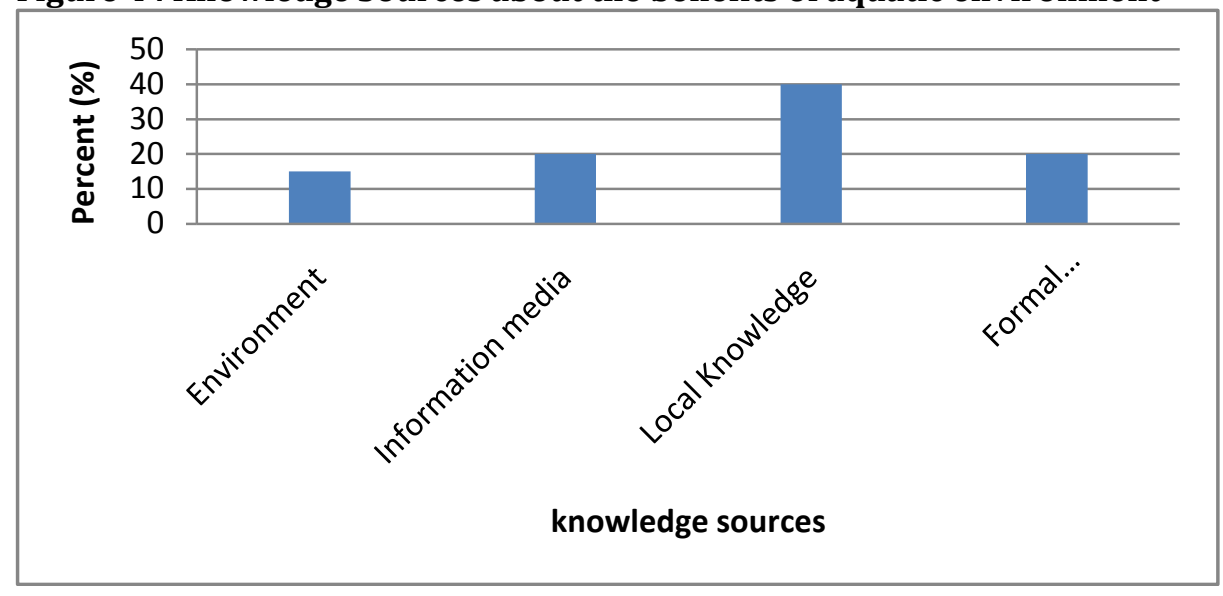

Concerning the utilization of the estuary and Gulf of Yos Sudarso areas, in view of the number of visits to the area, based on data analysis obtained, $30 \%$ of the local population conduct fishing activities at the site for both consumption and sale, $45 \%$ utilize the area for transportation, and $10 \%$ utilize the area for other activities, for example tourism.

Impacts of degradation of Water Quality: The environmental impacts of sedimentation include the following: loss of important or sensitive aquatic habitat, decrease in fishery resources, loss of recreational attributes, loss of coral reef communities, human health concerns, changes in fish migration, increases in erosion, loss of wetlands, nutrient balance changes, circulation changes, increases in turbidity, loss of submerged vegetation, and coastline alteration. Litter scattered on the beaches and floating in the Gulf of Yos Sudarso and estuarine waters is a problem, particularly non-biodegradable litter. It tangles in the appendages of marine life and is harmful to divers and beach users. Some fishing techniques may also cause habitat destruction. Blast fishing and cyanide fishing, which are illegal in many places, harm surrounding habitat. Dynamite fishing is another destructive method for gathering fish. Sticks of dynamite, grenades, or homemade explosives are detonated in the water. This method of fishing kills the fish within the main blast area, along with many unwanted reef animals. The blast also kills the corals in the area, eliminating the reef's structure, destroying habitat for the remaining fish and other animals important for reef health. Catching fish has become increasingly difficult in the estuary and the Gulf of Yos Sudarso, because the waters in both the estuary and the gulf have suffered silting and pollution, and also because the water is smelly, brown and contain garbage (domestic waste).

Community based Management: Based on these conditions the local governments, NGOs and several other stakeholders have conducted public awareness campaigns about the importance to keep the waters (sea and river) clean and healthy. However, these activities have been merely incidental. Dredging is one solution to reduce sedimentation in the mouth of the Anafre river. It is done 2 times a year (based on interviews in 2015). The purpose of dredging is to avoid a buildup of sediment washed downstream from upstream, so as not to encourage the particles to enter waters. Sediments accumulate due to the discharge of water from upstream to downstream (the current velocity in the river mouth is $0.02 \mathrm{sec}$ ), not only is sediment pilled but wastes from household waste are also piled on the Anafre river. The local community in Kayupulau understands how important water is for them, so they always clean up rubbish and maintain the cleanliness of their household environment. A good habit is being promoted in this community (e.g. not throw trash into the water). This initiative is also supported by the Provincial Office for Hygiene and Gardening Services (DKP) by routinely transporting the garbage every week and procure trash bins in every household. 


\section{Conclusion}

Conditions in the field indicate that the utilization of the river flow is not in accordance with government regulations; for instance, the regional banks of the river should not be used for various purposes but in fact they have been used for settlement, and many people dump wastes directly into the river. The magnitude of these impacts is in fact beneficial to the people, in that the local community has been doing maintenance in order to keep the rivers and the gulf of Yos Sudarso from sedimentation and pollution. In utilizing and maintaining the river and the Gulf of Yos Sudarso, many of the locals do it by tradition inherited from generation to generation, but some also do so by using relatively-new technology. Local environmental conditions have an influence on the way people use and maintain the rivers and the gulf of Yos Sudarso.

\section{References}

Dahuri, R. (2003). Keanekaragaman Hayati Laut. Aset Pembangunan Berkelanjutan Indonesia. Gramedia Pustaka Utama. Jakarta.

Kay, R. \& Alder, J. (1999). Coastal Management and Planning, E \& FN SPON, New York.

Moleong, L. J. (2000). Metode Penelitian Kualitatif. Bandung: Remaja Rosda Karya.

Sari, A. \& Dahlan, M. (2015). Pola Sebaran Sedimen di Teluk Yos Sudarso Kota Jayapura. Prosiding Simposium Nasional Kelautan dan Perikanan. Presented at October 5th 2015. Hasanuddin University. Makassar, 15-22.

Nikijuluw, V. P.H. (2002). Rezim Pengelolaan Sumberdaya Perikanan. P3R. Jakarta 